\title{
Adenosine deaminase activity in type 2 diabetes mellitus: does it have any role?
}

\author{
A. Niraula ${ }^{{ }^{*}}$ D, S. Thapa ${ }^{2}$, S. Kunwar ${ }^{3}$, M. Lamsal ${ }^{1}$, N. Baral ${ }^{1}$ and R. Maskey ${ }^{4}$
}

\begin{abstract}
Background: Diabetes mellitus is a group of metabolic disorders of carbohydrate metabolism in which glucose is underused, producing hyperglycemia. Diabetic patients are prone to opportunistic infection, thus serum ADA levels in these patients is very important as a screening test for Tuberculosis and autoimmune diseases. Thus, the present study was conducted to estimate the Serum ADA activity, glycated Haemoglobin (HbA1c), fasting and postprandial glucose level in patients with T2DM and to correlate the serum level of ADA with glycated Hemoglobin (HbA1c), fasting and postprandial glucose level in T2DM.

Methods: This is a Hospital based cross-sectional study done in BPKIHs, Dharan, Nepal. 204 diagnosed patients (102 males and 102 females) with T2DM and 102 healthy controls were enrolled in the study. Diabetic patients were categorized into Uncontrolled and Controlled Diabetes on the basis of $\mathrm{HbA} 1 \mathrm{C} ; \mathrm{HbA} 1 \mathrm{c}>7 \%=$ Uncontrolled Diabetes, $\mathrm{HbA} 1 \mathrm{c}<7 \%=$ Controlled Diabetes.

Results: Serum ADA levels (U/L) was significantly raised in Uncontrolled Diabetic patients (49.24 \pm 16.89$)$ compared to controlled population (35.74 \pm 16.78$)$ and healthy controls $(10.55 \pm 2.20)$, $p$ value $<0.001$. A significant positive correlation was obtained between Serum ADA and HbA1c, Fasting Plasma Glucose and Post-prandial Glucose respectively.

Conclusion: There is a significant increase in Serum ADA activity in DM with increase in HbA1c levels which may play an important role in predicting the glycemic and immunological status in these patients.
\end{abstract}

Keywords: Adenosine deaminase, Diabetes mellitus type2, Hemoglobin A1c protein human, Blood glucose/metabolism

\section{Background}

Diabetes mellitus (DM) refers to a group of common metabolic disorders that share the phenotype of hyperglycemia [1]. There is an estimated 143 million people worldwide suffering from diabetes [2], almost five times more than the estimates ten years ago. This number may probably double by the year 2030 [3]. Data in Southeast Asia highlights that more than 436,000 people have been affected by Type 2 diabetes Mellitus (T2DM) and there is a definite probability for the number rising to 1,328,000 by 2030 [4]. The chronic hyperglycemia of diabetes is associated with long-term damage, dysfunction, and failure of various organs, especially the eyes, kidneys, nerves, heart and blood vessels. Autoimmune destruction of the $\beta$ cells of the pancreas with consequent insulin deficiency and abnormalities that result in insulin resistance are the processes involved in the

\footnotetext{
*Correspondence: apekshyaniraula@gmail.com

${ }^{1}$ Department of Biochemistry, B.P. Koirala Institute of Health Sciences, Dharan, Nepal

Full list of author information is available at the end of the article
}

development of diabetes [5]. Also, T2DM has been always pigeon-holed as an intricate metabolic syndrome with multifactorial etiologies. The disease has been characterized by an atypical metabolism of all biomolecules i.e. carbohydrates, fats and proteins. Thus, collectively leading to an increased levels of blood glucose and lipid levels within the blood [6, 7].

Insulin resistance is associated with low-grade tissue specific inflammatory responses induced by various proinflammatory with oxidative stress mediators notably proinflammatory cytokines such as Interleukin-1 beta, Interleukin-6, Tumor Necrosis Factors- alpha along with numerous adipocytokines and chemokines, epigenetic factors and other transcriptional and metabolic pathways. Moreover, chronic exposure of pro-inflammatory mediators stimulates the activation of cytokine signaling proteins which ultimately block the activation of insulin signaling receptors in $\beta$-cells of pancreatic islets [7-9]. Adenosine deaminase (ADA) is a polymorphic enzyme

(c) The Author(s). 2018 Open Access This article is distributed under the terms of the Creative Commons Attribution 4.0 International License (http://creativecommons.org/licenses/by/4.0/), which permits unrestricted use, distribution, and reproduction in any medium, provided you give appropriate credit to the original author(s) and the source, provide a link to the Creative Commons license, and indicate if changes were made. The Creative Commons Public Domain Dedication waiver (http://creativecommons.org/publicdomain/zero/1.0/) applies to the data made available in this article, unless otherwise stated. 
that catalyzes the irreversible deamination of adenosine to inosine and has an important role in regulating adenosine concentration. Inosine and 2 '-deoxyinosine are converted to the metabolic products i.e. hypoxanthine, xanthine and consequently to uric acid [10]. ADA is still considered as a marker for the assessment of cell mediated immunity [11]. ADA is suggested to be an important enzyme for modulating the bioactivity of insulin [12], but its clinical significance in T2DM has not yet been proven. In cases of oxidative stress and cell membrane damage, serum ADA is increased [13].

Previously, ADA has been reported to be a marker for insulin function [10], [13]. But, the correlation between ADA in diabetic patients has not been studied extensively in our country. Even though there are some reports available on ADA levels in diabetic subjects, these are all inconclusive and controversial. Since a relationship exists between ADA and cell mediated immunity [14]. This study was undertaken as a preliminary study to determine its serum activity and highlight its importance in the immuno-pathogenesis of T2DM. Thus, the present study was conducted to estimate the Serum ADA activity, glycated Haemoglobin (HbA1c), fasting and postprandial glucose level in patients with T2DM and to correlate the serum level of ADA with glycated Hemoglobin (HbA1c), fasting and postprandial glucose level in T2DM.

\section{Methods}

\section{Study design}

Hospital based comparative cross-sectional study conducted in the Department of Internal Medicine and Department of Biochemistry at B. P. Koirala Institute of Health Sciences (BPKIHS), Dharan.

\section{Sample size}

Two hundred four patients diagnosed with T2DM. 102 healthy patients served as control.

\section{Sampling technique}

Diabetic patient were selected from medicine OPD by convenient sampling technique and the biochemical parameters was assessed in Department of Biochemistry, BPKIHS. Control patients were recruited from routine laboratory (Department of Biochemistry).

\section{Inclusion criteria}

Newly diagnosed and follow-up cases of T2DM visiting medicine OPD.

\section{Exclusion criteria}

Those having any other chronic disease. Patients having any complications due to diabetes.Blood was collected in EDTA and serum vial from the study population for fasting and postprandial blood glucose. Serum was separated and stored at $-20{ }^{\circ} \mathrm{C}$ until test was performed. Obtained serum sample was used for the analysis of biochemical parameters. Serum ADA was performed by the manual method described by Giusti and Galanti, (1984) [15]. The unit for ADA is expressed in Enzyme units/litre (U/L).

Sodium hypochlorite and phenol Enzyme cascade Adenosine $+\mathrm{H}_{2} \mathrm{O} \rightarrow$ Ammonia + Inosine

Alkaline Medium Ammonia+ Phenol+ Hypochlorite $\rightarrow$ Blue Indophenol Complex.

HbA1c was done by turbidimetric inhibition immunoassay (TINIA) method in Cobas c311 Autoanalyser [16]. $\mathrm{HbA} 1 \mathrm{c}$ is expressed in percentage (\%). The normal range is $4.5-6.3 \%$.

The HbA1c determination is based on the turbidimetric inhibition immunoassay (TINIA) for hemolyzed whole blood.

- Glycohemoglobin (HbA1c) in the sample reacts with anti-HbA1c antibody to form soluble antigen-antibody complexes. Only one specific HbA1c antibody site is present on the HbA1c molecule, complex formation does not take place.

- Addition of R2 (Polyhapten reagent) and start of reaction: The polyhaptens react with excess anti-HbA1c antibodies to form an insoluble antibody-polyhapten complex measured turbidimetrically

Fasting blood glucose (FPG) and Postprandial blood glucose (PPG) was done by Hexokinase Method (Cobas c311 Autoanalyser). FPG and PPG is expressed in $\mathrm{mg} / \mathrm{dl}$. DM was classified as Controlled and Uncontrolled on the basis of HbA1c level $(<7 \%=$ Controlled $\&>7 \%=$ Uncontrolled $)$ respectively. Data was collected and entered using Microsoft Excel ${ }^{\mathrm{Tm}}$ and analyzed using Statistical Package of Social science (SPSS) version 11.5. Data was expressed in terms of figure, percentage, mean and standard deviation. Independent sample t-test was used to compare the baseline and biochemical data between controlled and patients with T2DM. Analysis of variance (ANOVA) was used to compare the ADA level between healthy controls and controlled and uncontrolled T2DM. Spearman's correlation was applied to correlate serum ADA level with different markers for glycemic control viz., HbA1c, FPG and PPG respectively.

Ethical approval was taken as per the guidelines by Institutional Review Committee (IRC, BPKIHS) on October, 2015 (IRC No: 568/072/073-IRC).

\section{Results}

The study population comprised of total of 204 participants diagnosed of T2DM and 102 healthy controls. Demographic data has been depicted in Table 1. Biochemical parameters showed that Mean serum ADA was significantly higher in Diabetic patients compared to healthy controls as illustrated in Table 2. Further, ADA levels was significantly higher in 
Table 1 Baseline characteristics of the study population

\begin{tabular}{llll}
\hline Characteristics & Type 2 DM & Control & $p$ value \\
\hline Gender (Male/Female) & $103 / 101$ & $51 / 51$ & - \\
Age & $54.82 \pm 12.16$ & $45.5 \pm 10.4$ & $0.01^{\mathrm{a}^{*}}$ \\
Systolic Blood Pressure (SBP) (mm Hg) & $130 \pm 4.5$ & $110 \pm 5.6$ & $0.002^{\mathrm{a}^{*}}$ \\
Diastolic Blood Pressure (DBP) (mm Hg) & $95 \pm 5.8$ & $80 \pm 4.5$ & $0.04 \mathrm{a}^{\mathrm{a}^{*}}$ \\
BMl $\left(\mathrm{kg} / \mathrm{m}^{2}\right)$ & $26.12 \pm 1.8$ & $22.4 \pm 2.5$ & $0.022^{\mathrm{a}^{*}}$ \\
\hline
\end{tabular}

andependent sample t-test

${ }^{*} p$-value $<0.05$ is considered to be statistically significant

Uncontrolled T2DM than in controlled T2DM as shown in Table 3 respectively. Spearman's Correlation of FPG, PPG, and $\mathrm{HbA1c}$ with serum ADA showed a significant positive correlation with all of the three glycemic parameters. This suggests the use of ADA as an alternative marker of Glycemic control in Diabetic patients. Serum ADA showed a significant positive correlation with $\mathrm{HbA1c}$ which is considered as a good marker for long term glycemic control. Hence, it highlights the role of ADA as a potential marker for glycemic control as depicted in Table 4 .

\section{Discussion}

T2DM is the predominant form of diabetes worldwide, accounting for $90 \%$ of cases globally [17]. It is a multifactorial systemic disease with hereditary and environmental causes being the major attributable factor. These lead to insulin resistance and defective secretion of insulin by pancreatic beta-cell. Immunological disturbances of cell-mediated origin are believed to initiate from T-lymphocyte dysfunction. Invitro studies have shown that in T2DM, inappropriate immune responses may result from the defects in the action of insulin that is required for the function of T-lymphocytes [18]. ADA plays a crucial role in lymphocyte proliferation and differentiation and shows its highest activity in T- lymphocytes $[17,18]$. The present study shows a significant elevation in the ADA levels $(\mathrm{U} / \mathrm{L})$ in uncontrolled diabetic subjects $(49.24 \pm 16.89)$ compared to controlled population (35.74 \pm 16.78$)$. The high plasma ADA activity might be due to abnormal T-lymphocyte responses or proliferation; may point towards a mechanism that involves its release into the circulation $[19,20]$. Hence, we suggest that increased ADA

Table 2 Comparison of biochemical parameters in the study population

\begin{tabular}{llll}
\hline Biochemical Parameters & Type 2 DM & Control & $p$-value \\
\hline $\begin{array}{l}\text { Fasting Plasma Glucose } \\
\text { (FPG) (mg/dL) }\end{array}$ & $153.64 \pm 85.84$ & $90.24 \pm 25.54$ & $0.001^{a^{*}}$ \\
$\begin{array}{l}\text { Postprandial Glucose } \\
\text { (PPG) (mg/dL) }\end{array}$ & $242.72 \pm 136.63$ & $130.54 \pm 35.55$ & $0.001^{1^{*}}$ \\
HbA1c (\%) & $6.78 \pm 2.48$ & $3.4 \pm 0.55$ & $0.001^{1^{*}}$ \\
Serum ADA (Units/Litre) & $40.44 \pm 17.97$ & $10.55 \pm 2.20$ & $0.001^{1^{*}}$ \\
\hline
\end{tabular}

$\mathrm{a}=$ Independent sample t-test

${ }^{*} p$-value $<0.05$ is considered to be statistically significant
Table 3 Mean ADA level in healthy control, controlled and uncontrolled T2DM

\begin{tabular}{lll}
\hline Variables & Serum ADA & $p$-value \\
\hline Control & $10.55 \pm 2.20$ & $<0.001^{\text {a* }}$ \\
Controlled Diabetes Mellitus $(n=133)$ & $35.74 \pm 16.78$ & \\
Uncontrolled Diabetes Mellitus $(n=71)$ & $49.24 \pm 16.89$ & \\
${ }^{\text {aANOVA }}$ & \\
${ }^{*} p$-value $<0.05$ is considered to be statistically significant &
\end{tabular}

activity in diabetic individuals could be due to altered insulin related T-lymphocyte function or due to increased immunological dysfunction. Previously, Chang and Shaio, have demonstrated that impaired cell mediated immunity was associated with abnormal lymphocyte proliferation [21].

This study shows that ADA is raised in patients with diabetes mellitus, with values increasing in uncontrolled compared to controlled T2DM. Thus, the altered serum ADA levels may help in predicting immunological dysfunction in diabetic individuals. The present study depicts that there is a significant positive correlation between Serum ADA levels and Hbalc, which suggests that Serum ADA level can also be used as a biomarker in predicting glycemic control in diabetic patients. Studies have shown that there is a direct correlation with the expression and activity of ADA with the extent of severity of inflammation, as T2DM is associated with chronic hyperglycemia and an ongoing low-grade systemic inflammation [22]. The role of ADA in the cellular immunity was first identified in patients with severe combined immune-deficiency (SCID) [23, 24]. The high activity of this enzyme was considered to be a reflection of immunological disturbances observed in tuberculosis [25] infectious mononucleosis [26], jaundice [27], leukemia [28] and other conditions ( [29-31]).

\section{Conclusion}

Assessment of Serum ADA level is cost-effective and the efficient use of this biomarker may help in establishing this enzyme as a good marker for assessing cell-mediated immunity in diabetic individuals. Thus, we conclude that elevated ADA activity may be an important indicator in the

Table 4 Spearman's rho correlation correlating the level of ADA with FPG, PPG and Hba1c in T2DM

\begin{tabular}{lllll}
\hline Parameters & ADA & FPG & PPG & HbA1c \\
\hline ADA & - & 0.33 & 0.306 & 0.417 \\
& & $<0.001$ & $<0.001$ & $<0.001$ \\
FPG & 0.333 & - & 0.742 & 0.73 \\
& $<0.001$ & & $<0.001$ & $<0.001$ \\
PPG & 0.306 & 0.742 & - & 0.691 \\
& $<0.001$ & $<0.001$ & & $<0.001$ \\
HbA1c & 0.417 & 0.733 & 0.691 & - \\
& $<0.001$ & $<0.001$ & $<0.001$ & \\
\hline
\end{tabular}

${ }^{*} p$-value $<0.05$ is considered to be statistically significant 
immuno-pathogenesis of T2DM and can also be implicated as a biomarker for predicting glycemic control in diabetic individuals.

\section{Abbreviations}

DM: Diabetes Mellitus; FPG: Fasting plasma glucose; HbA1c: Glycated Hemoglobin; PPG: Post-prandial plasma glucose; T2DM: Type 2 Diabetes Mellitus

\section{Acknowledgements}

The authors would like to acknowledge Department of Biochemistry and Department of Internal Medicine for providing the platform and resources to conduct the study. They express sincere gratitude to the study participants without whom the study would not have been possible.

\section{Funding}

The author did not receive funding from any national and international organization to conduct the study.

\section{Availability of data and materials}

The datasets generated and/or analyzed during the current study are not publicly available due to the unavailability of disclosure of patient's identification but are available from the corresponding author on reasonable request.

\section{Author's contribution}

AN has designed the study, collected the history and blood samples from the study participants after the inclusion criteria has been met, done the required laboratory parameters on the blood samples on her own. The measurement of the analyte, statistical analysis of the data and writing of the paper has also been completed by the principal author. ST has contributed by the implementation of the idea by designing the study. He has been actively involved in statistical analysis and report writing of the study. SK has contributed during the sample collection and been actively involved in analysis of the analytes. He has also helped during the correction of the manuscript. ML is the guide of the principal author during her Postgraduate study. He has contributed as a supervisor and mentor to the author by helping in design of the study and during writing of the article. NB is one of the mentor of AN. He has helped in editing of the manuscript and have provided intense help for the final drafting of the article. RM has actively contributed during the sample collection with the proper diagnosis and also helped in the statistical analysis. All of the author mentioned above are genuine and have helped equally for the completion of the study. All authors have read and approve the final manuscript.

\section{Ethics approval and consent to participate}

This study has been approved and obtained the ethical clearance from Institutional Review Committee (IRC, BPKIHS). The ethical clearance number for the study is IRC/636/015.

All the study participants were enrolled only after obtaining the written informed consent.

\section{Consent for publication}

Not Applicable.

\section{Competing interests}

The authors declare that they have no competing interests for the publication of the study.

\section{Publisher's Note}

Springer Nature remains neutral with regard to jurisdictional claims in published maps and institutional affiliations.

\section{Author details}

'Department of Biochemistry, B.P. Koirala Institute of Health Sciences, Dharan, Nepal. ${ }^{2}$ Department of Biochemistry, Kathmandu University School of Medical Sciences, Kavre, Dhulikhel, Nepal. ${ }^{3}$ Department of Biochemistry, Modern Technical Institute, Satdobato, Lalitpur, Nepal. ${ }^{4}$ Department of Internal Medicine, B.P. Koirala Institute of Health Sciences, Dharan, Nepal.
Received: 13 November 2017 Accepted: 3 August 2018

Published online: 20 August 2018

\section{References}

1. Powers AC. Diabetes Mellitus. In: Harrison's Principles of Internal Medicine; 2012. p. 2968-3002.

2. King H, Aubert RE, Herman WH. Global burden of diabetes, 1995-2025: prevalence, numerical estimates, and projections. Diabetes Care. 1998;21(9): 1414-31.

3. Harris MI, Flegal KM, Cowie CC, Eberhardt MS, Goldstein DE, Little RR, et al. Prevalence of diabetes, impaired fasting glucose, and impaired glucose tolerance in U.S. adults. The Third National Health and Nutrition Examination Survey, 1988-1994. Diabetes care. 1998 Apr;21(4):518-24.

4. Wild S, Roglic G, Green A, Sicree R, King H. Global prevalence of diabetes: estimates for the year 2000 and projections for 2030. Diabetes Care. 2004 May;27(5):1047-53.

5. Vanitha Gowda MN, Vasudha KC, Reshma S, Sujatha KJ. Serum adenosine deaminase activity in type 2 diabetes mellitus patients. Int J Diabetes Dev Ctries. 2012;32(3):176-81.

6. Akash MSH, Rehman $\mathrm{K}$, Chen S. Role of inflammatory mechanisms in pathogenesis of type 2 diabetes mellitus. J Cell Biochem. 2013b;114:525-31.

7. Rehman K, Akash MS. Mechanisms of inflammatory responses and development of insulin resistance: How are they interlinked? J Biomed Sci. 2016;23:87.

8. Feve B, Bastard JP. The role of interleukins in insulin resistance and type 2 diabetes mellitus. Nat Rev Endocrinol. 2009:5(6):305-11.

9. Akash MSH, Shen Q, Rehman K, Chen S. Interleukin-1 receptor antagonist: a new therapy for type 2 diabetes mellitus. J Pharm Sci. 2012;101(5):1647-58.

10. Hoshino T, Yamada K, Masuoka K, Tsuboi I, Itoh K, Nonaka K, et al. Elevated adenosine deaminase activity in the serum of patients with diabetes mellitus. Diabetes Res Clin Pract. 1994;25(2):97-102.

11. Sullivan JL, Osborne WR, Wedgewood RJ. Adenosine deaminase activity in lymphocytes. Br J Haematol. 1977;37(1):157-8.

12. Franco $R$, Valenzuela $A$, Lluis C, Blanco J. Enzymatic and extraenzymatic role of ecto-adenosine deaminase in lymphocytes. Immunol Rev. 1998; $161: 27-42$.

13. Kurtul N, Pence S, Akarsu E, Kocoglu H, Aksoy Y, Aksoy H. Adenosine deaminase activity in the serum of type 2 diabetic patients. Acta Med (Hradec Kralove). 2004;47(1):33-5.

14. Baganha MF, Pêgo A, Lima MA, Gaspar EV, Cordeiro AR. Serum and pleural adenosine deaminase. Correlation with lymphocytic populations. Chest. 1990;97(3):605-10.

15. Giusti G, Galanti B. Colorimetric method. In: Bergmeyer 1W, ed. Methods of enzymatic analysis, 3rd ed. Weinheim: Verlag Cherme, 1984:315-23].

16. Roche Tina-quant Hemoglobin A1c Gen.2 - Hemolysate and Whole Blood Application package insert.

17. John B. Buse, Kenneth S. Polonsky C. Type 2 Diabetes Mellitus. In: William's textbook of Endocrinology. 2011. p. 1371-404

18. Stentz FB, Kitabchi AE. Activated T lymphocytes in type 2 diabetes: implications from in vitro studies. Curr Drug Targets. 2003;4(6):493-503.

19. Hovi T, Smyth JF, Allison AC, Williams SC. Role of adenosine deaminase in lymphocyte proliferation. Clin Exp Immunol. 1976;23(3):395-403.

20. Khemka VK, Bagchi D, Ghosh A, et al. Raised serum adenosine deaminase level in nonobese Type 2 Diabetes Mellitus. Te Scientifc World Journal. 2013; Article ID:404320:1-5.

21. Chang FY, Shaio MF. Decreased cell-mediated immunity in patients with noninsulin-dependent diabetes mellitus. Diabetes Res Clin Pract. 1995:28(2):137-46.

22. Desrosiers MD, Cembrola KM, Fakir MJ, et al. Adenosine deamination sustains dendritic cell activation in inflammation. J Immunol. 2007; 179:1884-92.

23. Giblett ER, Anderson JE, Cohen F, Pollara B, Meuwissen HJ. Adenosinedeaminase deficiency in two patients with severely impaired cellular immunity. Lancet (London, England). 1972;2(7786):1067-9.

24. Meuwissen HJ, Pollara B, Pickering RJ. Combined immunodeficiency disease associated with adenosine deaminase deficiency. Report on a workshop held in Albany, New York, October 1, 1973. J Pediatr. 1975; 86(2):169-81.

25. Pettersson T, Ojala K, Weber TH. Adenosine deaminase in the diagnosis of pleural effusions. Acta Med Scand. 1984;215(4):299-304. 
26. Koehler LH, Benz EJ. Serum adenosine deaminase: methodology and clinical applications. Clin Chem. 1962 Apr;8:133-40.

27. Dm G. Serum adenosine deaminase in the differential diagnosis of jaundice. Br Med J. 1965;1(5431):353-5.

28. Grever MR, Coleman MS, Balcerzak SP. Adenosine deaminase and terminal deoxynucleotidyl transferase: biochemical markers in the management of chronic myelogenous leukemia. Cancer Res. 1983;43(3):1442-5.

29. Mishra OP, Garg R, Ali Z, Usha. Adenosine deaminase activity in nephrotic syndrome. J Trop Pediatr. 1997;43(1):33-7.

30. Kavitha K, Devi PY, Prakash MS. Adenosine deaminase in cord blood as an immunoenzyme marker in low birth weight neonates. Indian J Med Sci. 2000;54(3):92-4.

31. Rani H. Surekha, Rao V. Dayasagar, Prakash M. Shiva, A. Jyothy. Serum adenosine deaminase activity and C-reactive protein levels in unstable angina. Indian J Hum Genet 2003; 9:17-20.

Ready to submit your research? Choose BMC and benefit from:

- fast, convenient online submission

- thorough peer review by experienced researchers in your field

- rapid publication on acceptance

- support for research data, including large and complex data types

- gold Open Access which fosters wider collaboration and increased citations

- maximum visibility for your research: over $100 \mathrm{M}$ website views per year

At BMC, research is always in progress.

Learn more biomedcentral.com/submissions 